\title{
Pengaruh Model Pembelajaran Think Pair Share Terhadap Hasil Belajar IImu Pengetahuan Alam
}

\author{
I G. Ari Sadiawan ${ }^{1}$, I M. Citra Wibawa ${ }^{2}$, P. Aditya Antara ${ }^{3}$ \\ 1,2 Jurusan PGSD, ${ }^{3}$ Jurusan PGPAUD, FIP \\ Universitas Pendidikan Ganesha \\ Singaraja, Indonesia \\ e-mail : arigede44@yahoo.co.id' ${ }^{1}$ imadecitra.wibawa@undiksha.ac.id ${ }^{2}$, \\ putuaditya.antara@undiksha.ac.id ${ }^{3}$
}

\begin{abstract}
Abstrak
Penelitian ini bertujuan untuk mengetahui perbedaan yang signifikan terhadap hasil belajar IPA antara kelompok siswa yang dibelajarkan dengan model pembelajaran Think Pair Share dan kelompok siswa yang dibelajarakan dengan model pembelajaran konvensional pada siswa kelas V semester II di Gugus I Kecamatan Tembuku tahun pelajaran 2017/2018. Jenis Penelitian ini adalah penelitian eksperimen semu (quasi eksperimen) dengan rancangan Posttest Only Control Design. Populasi ini adalah seluruh siswa kelas V gugus I kecamatan Tembuku berjumlah 128 siswa. Sebanyak 29 orang dipilih sebagai sampel yang ditentukan dengan teknik random sampling, yang terdiri dari 19 orang siswa kelas V SD N 1 Jehem sebagai kelompok eksperimen dan 20 siswa kelas V SD N 4 Jehem sebagai kelompok kontrol. Data dikumpulkan dengan metode tes berbentuk pilihan ganda. Hasil penelitian menunjukkan bahwa terdapat perbedaan yang signifikan dari hasil belajar IPA antara siswa yang dibelajarkan dengan model pembelajaran Think Pair Share dan siswa yang belajar dengan model pembelajaran Konvensional di SD Gugus I Kecamatan Tembuku Tahun Pelajaran 2017/2018. Hal ini ditunjukkan oleh thitung $(2,60)>$ ttabel $(2,03)$. Selanjutnya, rata-rata (mean) kelompok eksperimen $(30,26)$ lebih besar daripada rata-rata (mean) kelompok kontrol $(28,40)$. Dengan demikian, model pembelajaran think pair share berpengaruh positif terhadap hasil belajar IPA siswa kelas V SD di Gugus I Kecamatan Tembuku. Berdasarkan hal tersebut, saran dalam penelitian ini diupayakan untuk untuk menggunakan model pembelajaran yang inovatif salah satunya model pembelajaran think pair share
\end{abstract}

Kata-kata kunci: Hasil Belajar IPA, Think Pair Share

\begin{abstract}
This study aims to determine the significant differences to the results of science learning between groups of students who were taught by the model of learning Think Pair Share and groups of students who were educated with conventional learning model in V grade II students in the first group Tembuku Tembuku Year Lesson 2017/2018. This type of research is quasi experimental research (quasi experiment) with Post-test Design Only Control Design. This population is all students of class V Gugus I sub-district Tembuku Cermin 128 students. A total of 29 people were selected as samples determined by random sampling technique, consisting of 19 students of grade V SD N 1 Jehem as experimental group and 20 students of grade V SD $N 4$ Jehem as control group. Data were collected by multiple choice form test method. The results showed that there were significant differences of the learning outcomes between students who were studied with Think Pair Share and students learning with Conventional learning model in SD Gugus I Kecamatan Tembuku in Lesson 2017/2018. This is shown by thitung (2.60)> ttable (2.03). Furthermore, the mean (mean) experimental group (30.26) is greater than the control group's mean (mean) (28.40). Thus, the learning model of think pair share has a positive effect on the learning outcomes of science students of grade V SD in the first group of Tembuku sub district. Based on this, the suggestions in this research are attempted to use innovative learning model one of them is the thinking pair share learning model.
\end{abstract}

Keywords: Results of Science Learning, Think Pair Share 


\section{Pendahuluan}

Pendidikan adalah hal terpenting bagi setiap negara untuk dapat berkembang pesat. Negara yang hebat akan menempatkan pendidikan sebagai prioritas pertamanya, karena dengan pendidikan, kemiskinan pada rakyat di negara tersebut akan dapat tergantikan menjadi kesejahteraan. Bagaimanapun, dalam perkembangannya, pendidikan di Indonesia senantiasa harus menghadapi beberapa masalah di setiap tahapnya. Masalahmasalah tersebut hanya dapat diselesaikan dengan partisipasi dari semua pihak yang terkait di dalam sistem pendidikan, seperti orangtua, guru-guru, kepala sekolah, masyarakat, dan juga peserta didik itu sendiri. Pada fase input, orangtua memiliki kontribusi besar dalam memperkenalkan nilai-nilai baik kepada anak-anak mereka. Orangtua bertanggung jawab penuh untuk mendidik anak-anak mereka dengan nilai-nilai kepemimpinan, sehingga mereka mempunyai bekal yang cukup untuk menjadi cikal bakal pemimpin ketika mereka mulai memasuki institusi formal, seperti sekolah. Pada fase proses, orangtua bekerjasama dengan para guru dan kepala sekolah untuk memberikan penguatan kepada peserta didik dalam menerapkan nilai-nilai kepempinan yang baik melalui budaya organisasi di sekolah. Terakhir, pada tahap output, peserta didik harus menghadapi begitu banyak tantangan di dunia nyata, di luar sekolah. Peserta didik yang sudah melalui tahap-tahap sebelumnya di sekolah dengan budaya organisasi yang mengajarkan dan membiasakan nilai-nilai baik dalam hidupnya, maka akan tumbuh menjadi pemimpin yang hebat untuk negara ini (Megawati, 2012).

Pendidikan merupakan sesuatu yang sangat penting dalam suatu negara. Melalui proses pendidikan seseorang akan dapat mengembangkan bakat yang dimilikinya sehingga mengantarkannya menjadi sumber daya manusia yang kompetitif. Kemajuan suatu negara tidak terlepas dari kemajuan kualitas pendidikannya. Perkembangan ilmu pengetahuan dan teknologi yang semakin pesat dan perlu direspon oleh kinerja pendidikan yang profesional dan bermutu tinggi. Kualitas pendidikan yang bermutu tinggi sangat diperlukan untuk mendukung terciptanya manusia cerdas dan terampil agar bisa bersaing secara terbuka di era globalisasi saat ini. Maka dari itu perlu adanya pembenahan dan penyempurnaan terhadap aspek substansif yang mendukung, yaitu kurikulum dan tenaga profesional.

Pendidikan juga merupakan sebuah sistem. Sebagai sistem, aktivitas pendidikan terbangun dalam beberapa komponen, yaitu pendidik, peserta didik, tujuan pendidikan, alat pendidikan, dan lingkungan pendidikan. Semua komponen yang membangun sistem pendidikan, saling berhubungan, saling tergantung, dan saling menentukan satu sama lain. Setiap komponen memiliki fungsi masing-masing dalam rangka mencapai tujuan pendidikan. Aktivitas pendidikan akan terselenggara dengan baik apabila didukung oleh komponenkomponen dimaksud. Fungsi pendidikan sebenarnya adalah menyediakan fasilitas yang dapat memungkinkan tugas pendidikan dapat berjalan lancar, baik secara struktural, maupun secara institusional. Secara struktural menuntut terwujudnya struktur organisasi yang mengatur jalannya proses kependidikan. Secara institusional mengandung implikasi bahwa proses kependidikan yang terjadi dalam struktur organisasi itu dilembagakan untuk lebih menjamin proses pendidikan itu berjalan secara konsisten dan berkesinambungan mengikuti kebutuhan dan perkembangan manusia yang cenderung ke arah tingkat kemampuan yang optimal (Saat, 2015).

Pasal 1 UU SISDIKNAS no. 20 tahun 2003 disebutkan bahwa Sistem Pendidikan Nasional adalah keseluruhan komponen pendidikan yang saling terkait secara terpadu untuk mencapai tujuan pendidikan nasional. Berangkat dari bunyi pasal ini dapat diketahui bahwa pendidikan adalah sistem yang merupakan suatu totalitas struktur yang terdiri dari komponen yang saling terkait dan secara bersama menuju kepada tercapainya tujuan (Soetarno, 2003: 2). Adapun komponen-komponen dalam pendidikan nasional antara lain adalah lingkungan, sarana-prasarana, sumberdaya, dan masyarakat. Komponen-komponen tersebut bekerja secara bersama-sama, saling terkait dan mendukung dalam mencapai tujuan pendidikan. Tujuan pendidikan nasional yang dirumuskan dalam UU SISDIKNAS adalah untuk mengembangkan potensi anak didik agar menjadi manusia yang beriman dan bertakwa kepada Tuhan Yang Maha Esa, berakhlak mulia, sehat, berilmu, cakap, kreatif, mandiri, dan menjadi warga Negara yang demokratis serta bertanggung jawab (Munirah, 2015).

Sistem pendidikan nasional adalah keseluruhan komponen pendidikan yang saling terkait secara terpadu untuk mencapai tujuan pendidikan nasional (UUSPN Nomor 3 Bab 1 Pasl 1). Berbagai upaya telah dilakukan oleh pemerintah berkaitan dengan peningkatan mutu pendidikan saat ini. Beberapa upaya tersebut diantarannya adalah dengan menyempurnakan kurikulum pendidikan. Saat ini telah dilakukan penyempurnaan kurikulum dari kurikulum 2004 
yang sering disebut Kurikulum Berbasis Kompetensi (KBK), selanjutnya menjadi kurikulum 2006 yang sering disebut Kurikulum Tingkat Satuan Pendidikan (KTSP), dan selanjutnya menjadi Kurikulum 2013. Namun saat ini masih beberapa sekolah yang menggunakan kurikulum 2013. Negara Indonesia kini diberlakukan dua kurikulum yaitu kurikulum 2013 dan kurikulum KTSP.

Dalam KTSP, diharapkan terjadinya perubahan dari proses pembelajaran yang cendrung pasif, teoritis, dan berpusat kepada guru (teacher center) menjadi pembelajaran aktif, kreeatif, dan produktif yang mengacu pada permasalahan kontekstual dan berpusat pada siswa (Depdiknas, 2006). Tugas dan peranan guru tidak lagi sebagai pemberi informasi, tetapi sebagai pendorong belajar agar siswa dapat menemukan kembali dan mengkontruksi pengetahuannya sendiri.

Peningkatan kualitas pendidikan dicerminkan oleh prestasi belajar siswa, sedangkan keberhasilan atau prestasi belajar siswa dipengaruhi oleh kualitas pendidikan yang bagus. Untuk keberhasilan peningkatan mutu pendidikan perlu adanya pengembangan dan pembaharuan strategi pembelajaran. Strategi pembelajaran tersebut hendaknya mendukung tercapainya pengajaran yaitu agar siswa dapat berfikir aktif dan diberi kesempatan untuk mencoba dalam berbagai kegiatan belajar. Inti kegiatan dari pembelajaran adalah proses pembelajaran.

Belajar merupakan proses perkembangan ke arah yang lebih sempurna. Belajar merupakan salah satu kebutuhan hidup manusia yang paling penting dalam upaya mempertahankan hidup dan mengembangkan diri. Melalui belajar seseorang dapat memahami suatu konsep yang baru atau mengalami perubahan tingkah laku, sikap dan keterampilan. Dengan belajar diharapkan siswa memperoleh hasil belajar yang baik. hasil belajar yaitu perubahan-perubahan yang terjadi pada diri siswa, baik yang menyangkut aspek kognitif, afektif, dan psikomotor sebgai hasil dari kegiatan belajar" (Susanto, 2013: 6). Bloom (dalam Ruhimat, 2013:140) "ada tiga ranah hasil belajar yaitu: kognitif, afektif, dan psikomotor. Secara sederhana hasil belajar siswa dapat diartikan sebagai kemampuan siswa yang dapat diperoleh setelah melalui tahapan belajar karena belajar itu sendiri adalah bentuk usaha seseorang dalam memperoleh perubahan perilaku yang relative menetap

Proses belajar mengajar melibatkan interaksi antara guru dengan siswa. Di dalam proses pembelajaran, guru sebagai pengajar dan fasilitator belajar sedangkan siswa berperan sebagai pelajar. Dalam proses pembelajaran masih banyak siswa yang sering mengabaikan proses pembelajaran dengan bercanda dengan teman sebangku, hal ini mengakibatkan turunnya prestasi belajara siswa. Namun kecendrungan guru saat mengajar, para guru biasanya masih menerapkan pembelajaran yang lebih berpusat pada guru, seperti metode ceramah. Metode ceramah memang sangat penting didalam proses pembelajaran, akan tetapi siswa lebih mudah mengingat dan mengerti apa yang dipelajari jika siswa terlibat langsung didalamnya. Dengan melibatkan siswa secara langsung dalam proses pembelajaran, pemahaman siswa terhadap pembelajaran akan lebih maksimal. Dengan pemahaman yang maksimal, maka tujuan pembelajaran akan lebih mudah tercapai. Salah satu mata pelajaran yang termuat dalam kurikulum adalah mata pelajaran IPA.

Menurut Suprijono (2012:5), hasil belajar adalah polapola perbuatan, nilai-nilai, pengertian-pengertian, sikapsikap, apresiasi dan keterampilan. Selanjutnya Supratiknya (2012: 5) mengemukakan bahwa hasil belajar yang menjadi objek penilaian kelas berupa kemampuankemampuan baru yang diperoleh siswa setelah mereka mengikuti proses belajar-mengajar tentang mata pelajaran tertentu. Dalam sistem pendidikan nasional rumusan tujuan pendidikan mengacu pada klasifikasi hasil belajar dari Bloom yang secara garis besar yaitu aspek kognitif, aspek afektif dan aspek psikomotor (Widodo, 2013).

Guru merupakan salah satu faktor yang sangat menentukan keberhasilan pembelajaran di sekolah. Dalam proses pembelajaran, guru harus dapat mempersiapkan rancangan pembelajaran yang baik sebagai acuan dalam kegiatan proses pembelajaran di kelas. Hal ini dapat dilakukan melalui pemilihan strategi dan model pembelajaran yang relevan sesuai dengan tingkat perkembangan mental siswa, lingkungan sekolah, dan karakteristik materi pelajaran sehingga siswa dapat mengembangkan pengetahuannya. Santyasa (2012) menyatakan bahwa "penerapan suatu model pembelajaran merupakan hal yang penting dalam pembelajaran untuk menciptakan lingkungan belajar yang mendukung pencapaian tujuan belajar yang lebih baik". Oleh sebab itu, guru harus mampu menerapkan dengan baik dan tepat strategi, model maupun metode pembelajaran.

Guru juga harus mampu menjadi ilmuwan dan intelektual dalam arti sebagai sumber ilmu, sumber pengetahuan, dan memberikan pencerahan bagi peserta didiknya. Guru menjadi tempat bertanya bagi orang yang tidak tahu, dan menjadi obor bagi mereka yang berada dalam 
kegelapan. Meskipun, tidak harus menjadikan dirinya superior yang menganggap bahwa gurulah yang paling benar. Sikap kaum ilmuwan dan intelektual adalah menghargai dan menghormmati perbedaan pendapat, dan menjunjung tinggi kebenaran atas dasar fakta dan logika yang sehat. Peran guru sebagai ilmuwan dan intelektual ini telah ada dalam pepatah Jawa. Yakni, guru itu digugu lan ditiru. Digugu berarti guru memiliki pengetahuan yang luas, sehingga bisa menjadi sumber informasi, dan penerang gelapnya alam pikiran. Ditiru, berarti guru memiliki moralitas dan integritas, sehingga perilakunya bisa dijadikan teladan (Warsono, 2017).

IPA merupakan konsep pembelajaran alam dan mempunyai hubungan yang sangat luas terkait dengan kehidupan manusia. Pembelajaran IPA sangat berperan dalam proses pendidikan dan juga perkembangan Teknologi, karena IPA memiliki upaya untuk membangkitkan minat manusia serta kemampuan dalam mengembangkan ilmu pengetahuan dan teknologi serta pemahaman tentang alam semesta yang mempunyai banyak fakta yang belum terungkap dan masih bersifat rahasia sehingga hasil penemuannya dapat dikembangkan menjadi ilmu pengetahuan alam yang baru dan dapat diterapkan dalam kehidupan sehari-hari.

Menurut Giri, (2014) Kegiatan pembelajaran IPA siswa diharapkan dapat mengembangkan kemampuan berpikirnya dengan cara mengkontruksikan pengetahuannya secara mandiri, kritis dan kreatif sehingga siswa dapat memiliki sikap peka dan tanggap untuk bertindak secara rasional, serta bertanggung jawab dalam memecahkan masalah-masalah yang dihadapi dalam kehidupannya. Dengan demikian dapat memberikan pengalaman bermakna yang merupakan persiapan dalam kehidupan sebenarnya di masyarakat. Pengertian IPA menurut Susanto, dalam Riastini (2016:4), merupakan usaha manusia dalam memahami alam semesta melalui pengamatan yang tepat pada sasaran, serta menggunakan prosedur, dan dijelaskan dengan penalaran sehingga mendapatkan kesimpulan. Berdasarkan pengertian tersebut, IPA dapat dibagi menjadi tiga, yaitu IPA sebagai produk, proses dan sikap. Sikap yang dimaksud adalah sikap ilmiah yang dimiliki oleh para ilmuan. Peran guru dalam pembelajaran IPA diharapkan berfungsi sebagai fasilitator, mediator, dan motifator sehingga siswa memiliki peran yang lebih banyak dibandingkan dengan guru itu sendiri.

Menurut Giri, (2014) Seharusnya pada mata pelajaran IPA guru ditekankan mengunakan model dan media pembelajaran karena dalam mata pelajaran IPA sangatlah diperlukan model dan media pembelajaran. Di dalam proses pembelajaran guru juga jarang memberikan pertanyaan yang memiliki jawaban bebas yang sering disebut pertanyaan terbuka. Seorang guru seharusnya bisa menggali pengetahuan siswa dengan baik, seorang guru haruslah terampil dalam merancang pertanyaan agar bisa menggali pengetahuan siswa lebih banyak lagi dengan menggunakan pertanyaan terbuka dan pertanyaan tertutup. Jika siswa diberikan pertanyaan terbuka maka siswa dapat memberikan jawaban secara luas sesuai dengan pengetahuan dan pengalaman yang mereka miliki.

Berdasarkan pertanyaan yang diberikan guru kepada siswa terlihat pengetahuan siswa pada mata pelajaran IPA masih rendah. Dengan kenyataan para guru mengajar hanya berdasarkan buku-buku pegangan yang ada dan mengandalkan ceramah, sehingga pertanyaan yang diberikan kepada siswa hanyalah pertanyaan tertutup yang ada pada buku saja. Saat observasi juga terlihat suasana proses pembelajaran kurang menyenangkan dirasakan oleh siswa serta proses pembelajaran masih bersifat satu arah yaitu berpusat pada guru

Berdasarkan observasi yang dilakukan di SD Negeri 1 Jehem, bahwa guru kurang mengembangkan model pembelajaran serta membuat media pembelajaran karena kebanyakan dari guru mempunyai kesibukan yang padat sehingga alasan itupun yang membuat guru tidak membuat media pembelajaran, namun jika ada media di sekolah guru terkadang menggunakan media yang ada. Selain itu alasan guru menggunakan model pembelajaran konvensional karena guru sudah terlanjur membuat RPP menggunakan model konvensional (ceramah) tetapi pada RPP yang saya lihat ada beberapa yang menggunakan model pembelajaran lain namun langkah pembelajarannya tidak sesuai dengan sintaks model pembelajaran tersebut.

Berdasarkan hasil wawancara yang dilakukan di dalam kelas dan di luar kelas pada tanggal 27 November 2017 dengan Bapak Ketut Dana yang merupakan salah satu guru kelas V di SD Gugus I Kecamatan Tembuku, memperlihatkan masalah yang dialami siswa pada mata pelajaran IPA. Dari hasil wawancara mendapatkan informasi bahwa: 1) mata pelajaran IPA merupakan mata pelajaran yang kurang menarik bagi siswa, 2) siswa cendrung sulit memahami materi yang diajarkan, 3) siswa cendrung pasif dan cepat bosan dalam pembelajaran, 4) sebagian besar siswa juga kesulitan dalam menjelaskan kembali tentang konsep materi pelajaran yang telah mereka pelajari 5) siswa sulit berkonsentrasi terhadap pembelajaran karena dalam proses pembelajaran tidak menggunakan model pembelajaran yang inovatif, 6 ) 
mereka lebih suka mencoret-coret buku, atau bercanda dengan teman sebangkunya, dan disekolah tersebut sangat kekurang media-media kongkret guna menunjang kegiatan pembelajaran dan. hal ini terlihat dari rendahnya hasil belajar IPA SD di Gugus I Kecamatan Tembuku, Kabupaten Bangli. Dapat dilihat pada tabel berikut.

Menurut Bloom (dalam Antara 2013:247) menyatakan,mengungkapkan tingkat kognitif yang terdiri dari enam tingkatan yaitu mengingat (C1), memahami (C2), menerapkan (C3), menguraikan/analisis (C4), menggabungkan/sintesis (C5), menilai/evaluasi (C6). Dalam penelitian ini baru mencapai tingkatan menerapkan (C3) karena pada proses pembelajaran dan target pencapaian hasil belajar pada pelajaran IPA siswa banyak ditemui di SD baru mencapai tingkat menerapkan.

Menindaklanjuti dari hasil wawancara dan observasi yang diperoleh di Gugus I Kecamatan Tembuku, untuk menanggulangi permasalahan tersebut perlu dilakukan perbaikan dan inovasi dalam proses pembelajaran IPA. Dalam pembelajaran IPA bukan hanya menyediakan peluang pada siswa untuk belajar tentang fakta dan teori-teori saja, tetapi juga mengembangkan kebiasaan dan sikap berpikir ilmiah. Untuk itu guru diharapkan dapat menerapkan model pembelajaran yang inovatif. Maka salah satu solusi yang bisa ditawarkan untuk meningkatkan kompetensi IPA siswa dalam kegiatan pembelajaran adalah dengan cara menerapkan model pembelajaran Think Pair Share (TPS) yaitu Berfikir, Berpasangan dan Berbagi, yang menuntut siswa agar memiliki otonomi penuh dalam melakukan pengaturan cara dan kondisi yang terbaik bagi dirinya untuk belajar, yang terkait dengan pembelajaran IPA.

Tujuan penelitian ini yaitu Untuk mengetahui perbedaan yang signifikan terhadap hasil belajar IPA antara kelompok siswa yang dibelajarkan dengan model pembelajaran Think Pair Share dan kelompok siswa yang dibelajarakan dengan model pembelajaran konvensional pada siswa kelas V semester II di Gugus I Kecamatan Tembuku tahun pelajaran 2017/2018.

\section{Metode}

Jenis penelitian yang digunakan dalam penelitian ini adalah penelitian eksperimen semu (quasi eksperiment). Hal ini dikarenakan oleh semua variabel yang muncul dan kondisi eksperimen tidak mungkin dapat diatur dan dikontrol secara ketat (full randomize). Penelitian ini menggunakan rancangan desain penelitian post-test only control design. Populasi dalam penelitian ini adalah seluruh siswa kelas V SD di Gugus I Kecamatan Tembuku. Banyak populasi dalam penelitian ini adalah 128 siswa yang tersebar ke dalam tujuh sekolah yang ada di Gugus I Kecamatan Tembuku, yaitu kelas V di SD Negeri 1 Jehem, SD Negeri 2 Jehem, SD Negeri 3 Jehem, SD Negeri 4 Jehem, SD Negeri 5 Jehem, SD Negeri 6 Jehem ,SD Negeri 7 Jehem.

Sebelum menentukan sampel populasi tersebut, akan diuji kesetaraannya untuk mengetahui kemampuan siswa kelas V masing-masing SD di Gugus I Kecamatan Tembuku setara atau tidak. Uji kesetaraan populasi dilakukan dengan cara melakukan uji kesetaraan terhadap nilai ulangan tengah semester mata pelajaran IPA semester ganjil tahun pelajaran 2017/2018. Rumus yang digunakan untuk menguji kesetaraan populasi tersebut adalah dengan menggunakan analisis varians satu jalur (ANAVA A). Hasil dari uji kesetaraan yaitu tidak terdapat perbedaan yang signifikan hasil belajar IPA siswa kelas V pada Gugus I Kecamatan Tembuku. Hasil tersebut menunjukkan bahwa nilai siswa kelas V gugus I Kecamatan Tembuku dinyatakan setara.

Setelah melalui proses yang diharapkan, didapat sampel berdasarkan random, yakni SD Negeri 1 Jehem sebagai kelompok eksperimen dan SD Negeri 4 Jehem sebagai kelompok kontrol. Adapun variabel penelitian ini terdiri atas variabel terikat, yakni hasil belajar IPA dan variabel bebas, yakni model pembelajaran Think Pair Share.

Prosedur penelitian dilakukan dalam tiga tahap yaitu persiapan eksperimen yang terdiri dari persiapan instrumen penelitian dan perangkat pembelajaran yaitu Rencana Pelaksanaan Pembelajaran (RPP), pelaksanaan eksperimen yang dilakukan dengan pemberian treatment sebanyak tujuh kali pada kelompok eksperimen dan tujuh kali pembelajaran pada kelompok kontrol Untuk kelas eksperimen, yaitu pemberian model pembelajaran Think Pair Share, dan tujuh kali pelaksanaan kegiatan pembelajaran konvensional untuk kelas kontrol. Adapun langkah-langkah pembelajara Think Pair Share yaitu berpikir, berpasangan, berbagi. Akhir eksperimen dilakukan dengan pemberian post-tes sebanyak satu kali pada kelompok eksperimen dan kelompok kontrol, dengan soal yang telah diuji oleh ahli/judges.

Pada tahap persiapan eksperimen, khususnya persiapan instrumen penelitian, setelah tes lolos uji ahli/judges, dilakukan uji validitas tes untuk menentukan butir soal yang layak untuk 
diberikan kepada siswa pada saat pemberian post-test. Adapun hasil uji validitas isi sebesar 1,0 yang termasuk dalam kategori sangat tinggi. Kemudian hasil uji validitas butir tes menunjukkan bahwa dari 40 butir soal yang diuji cobakan, diperoleh 35 butir soal yang dinyatakan valid, yang berarti 5 butir soal tidak valid. Hal ini ditunjukkan dengan $r_{\text {hit }}>r_{\text {tab }}\left(r_{\text {tab }}=0,2876\right.$ dengan $\left.N=47\right)$. Sedangkan hasil uji reliabilitas tes sebesar 0,82 yang berkualifikasi sangat tinggi. Jadi instrumen tersebut layak dan dapat dipercaya untuk digunakan sebagai alat pengumpulan data. Hasil Uji daya beda butir tes menunjukkan bahwa diperoleh 1 butir soal memiliki daya beda kurang, 22 butir soal memiliki daya pembeda cukup baik, 12 butir soal yang memiliki daya pembeda baik. Sedangkan hasil daya beda tes sebesar $\mathrm{Dp}=0,39$ yang tergolong dalam kriteria cukup. Berdasarkan penghitungan indeks kesukaran butir soal, diperoleh hasil 10 butir soal yang tergolong mudah, 18 butir soal tergolong sedang, dan 7 butir soal tergolong sukar.

Metode pengumpulan data dalam penelitian ini menggunakan metode tes sehingga instrumen yang digunakan dalam penelitian ini adalah tes pilihan ganda. Data yang dikumpulkan dianalisis menggunakan analisis statistik deskriptif dan statistik inferensial. Sebelum dilakukan uji hipotesis, dilakukan uji prasyarat yaitu normalitas dan homogenitas. Kemudian dilanjutkan dengan uji hipotesis menggunakan uji-t

\section{Hasil dan Pembahasan}

Hasil analisis data yang telah dilakukan, dapat disajikan dalam rekapitulasi data hasil belajar IPA siswa kelompok eksperimen dan kelompok kontrol pada Tabel 1.

Tabel 1. Ringkasan Analisi hasil belajar Ipa kelompok Eksperimen dan kelompok kontrol

\begin{tabular}{ccc}
\hline Hasil & Kelompok Eksperimen & Kelompok Kontrol \\
\hline Mean & 30,26 & 28,40 \\
\hline Median & 30,50 & 28,17 \\
\hline Modus & 30,83 & 27,50 \\
\hline Standar Deviasi & 2,28 & 2,19 \\
\hline Varian & 5,20 & 4,78 \\
\hline
\end{tabular}

Berdasarkan Tabel 1, pencapaian skor rata-rata hasil belajar IPA pada kelompok eksperimen dengan kategori sangat baik $(M=30,26)$, varian sebesar 5,20 dan standar deviasi 2,28 . Pada kelompok kontrol, skor rata-rata berada pada kategori baik $(M=28,40) 28,40$ dengan varian sebesar 4,78 dan standar deviasi 2,19. Secara deskriptif dapat disampaikan bahwa pengaruh model pembelajaran Think Pair Share lebih unggul dibandingkan dengan model pembelajaran konvensional untuk pencapaian hasil belajar IPA siswa kelas V SD di gugus I Kecamatan Tembuku.

Hasil penghitungan dari mean, median, dan modus dapat di sajikan ke dalam bentuk grafik sebagai berikut.

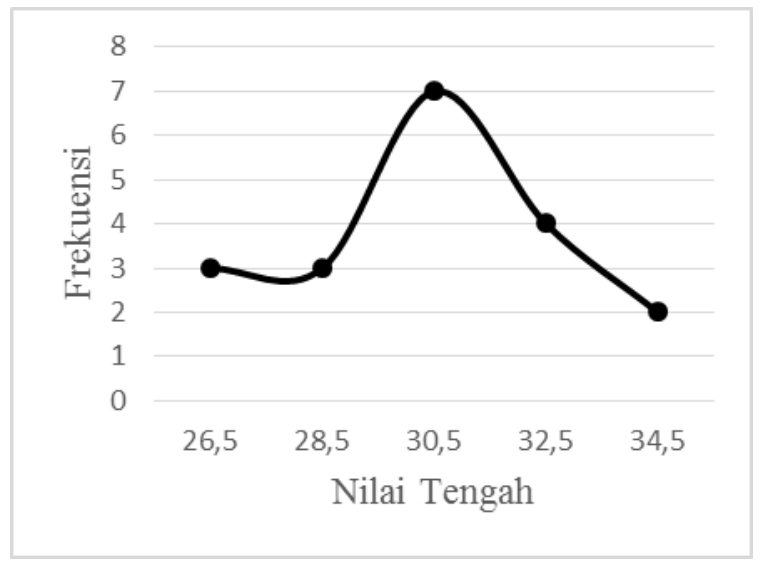

Gambar 1. Kurva Juling Positif Data Hasil Post-test Kelompok Eksperimen

Berdasarkan poligon pada Gambar 1, diketahui modus lebih besar dari median dan median lebih besar dari mean ( $M<M d<M o)$ yaitu $30,26<30,50<30,83$, sehingga kurva juling 
negatif yang berarti sebagian besar skor cenderung tinggi.. Sedangkan kurva poligon untuk kelas kontrol dapat dilihat pada gambar 2 .

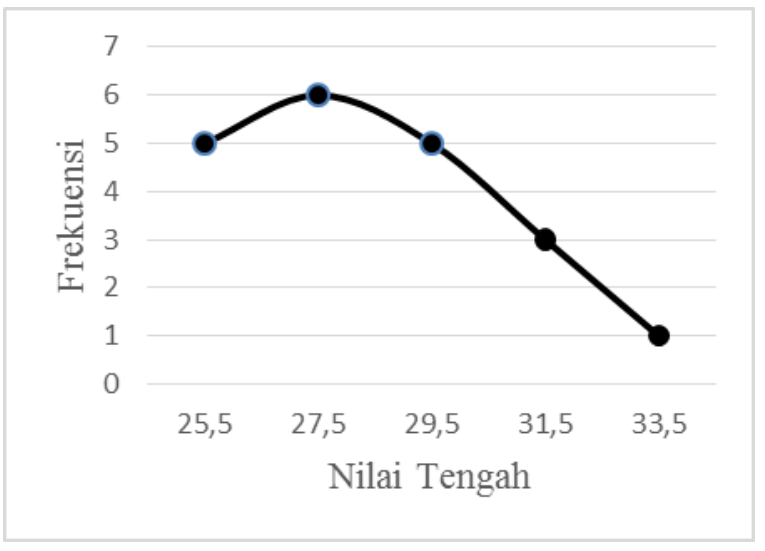

\section{Gambar 2. Kurva Juling Negatif Data Hasil Post-test Kelompok Kontrol}

Berdasarkan poligon pada Gambar 2, diketahui diketahui mean lebih besar dari median dan median lebih besar dari modus (M>Md>Mo) yaitu 28,40 >28,17 $>27,50$, sehingga kurva juling positif yang berarti sebagian besar skor cenderung rendah.. Sebelum dilakukan pengujian hipotesis terlebih dulu dilakukan uji prasyarat yaitu uji normalitas dan uji homogenitas. Berdasarkan hasil pengujian prasyarat diperoleh bahwa data hasil belajar IPA kelompok eksperimen dan kontrol berdistribusi normal. Hal ini diperoleh dari hasil penghitungan dengan $\mathrm{x}^{2}{ }_{\text {hit }}=2,15$ pada taraf signifikansi $5 \%$, sedangkan dengan $\mathrm{dk}=2$ diketahui $\mathrm{x}_{\text {tab }}^{2}=5,591$. Jadi, $\mathrm{x}^{2}{ }_{\text {hit }}<\mathrm{x}_{\text {tab }}^{2}$ yang berarti data hasil post-test siswa kelompok eksperimen berdistribusi normal. Sedangkan Chi-kuadrat data hasil post-test kelas kontrol $\left(\mathrm{x}^{2}\right.$ hit $)$ adalah 1,75 pada taraf signifikansi $5 \%$ dan $\mathrm{dk}=2$ diketahui $\mathrm{x}_{\text {tab }}^{2}=5,591$. Maka $\mathrm{x}_{\text {hit }}^{2}<\mathrm{x}^{2}$ tab yang berarti data hasil posttest kelompok kontrol berdistribusi normal. Kemudian setelah dilakukan penghitungan pada varians diperoleh $\mathrm{F}_{\text {hit }}=1,09$, sedangkan $\mathrm{F}_{\text {tab }}$ pada taraf signifikansi $5 \%$ serta dk pembilang 20 dan dk penyebut 19 adalah 2,18. Hasil ini menunjukkan $F_{\text {hit }}<F_{\text {tab }}$ sehingga $H_{0}$ diterima dan varians homogen. Jadi berdasarkan hasil penghitungan tersebut, diketahui bahwa data normal dan varians homogen, sehingga untuk menguji hipotesis menggunakan uji dapat dilanjutkan dengan uji hipotesis. antar kelompok eksperimen dan kontrol. Uji hipotesis dihitung dengan menggunakan rumus uji-t. Hasil uji hipotesis I dapat dilihat pada Tabel 2 di bawah ini:

Tabel 2. Rangkuman Hasil Uji Hipotesis

\begin{tabular}{lllllll}
\hline Kelompok & $\mathrm{N}$ & $\mathrm{Dk}$ & & $\mathrm{SD}$ & $\mathrm{t}_{\text {hit }}$ & $\mathrm{t}_{\text {tab }}$ \\
\hline Eksperimen & 19 & 37 & 30,26 & 2,28 & 2,60 & 2,03 \\
Kontrol & 20 & 37 & 28,40 & 2,19 & & \\
\hline
\end{tabular}

Berdasarkan Tabel 2, menunjukkan bahwa skor rata-rata kelompok eksperimen lebih besar dari skor rata-rata kelompok kontrol $\left(x^{-}=30,26>x^{-}=28,40\right)$. Hal ini berarti, pembelajaran dengan menggunakan model pembelajaran Think Pair Share terhadap hasil belajar IPA siswa, lebih baik dibandingkan dengan penggunaan model pembelajaran konvensional. Tinggnya skor rata-rata pada kelompok eksperimen berpengaruh positif terhadap pengujian hipotesis yang dilakukan dengan menggunakan uji-t. Hasil perhitungan uji-t diperoleh thit $=2,60$ dan ttab $=$ 2,03. Hal ini menunjukkan thit $>$ ttab, sehingga $\mathrm{HO}$ ditolak dan Ha diterima.

Berdasarkan perhitungan uji-t, dapat diinterpretasikan bahwa terdapat perbedaan yang signifikan pada hasil belajar IPA antara kelompok siswa yang belajar menggunakan model pembelajaran Think Pair Share dengan siswa yang belajar menggunakan model pembelajaran konvensional. Berdasarkan deskripsi data hasil penelitian, diketahui bahwa kelompok siswa yang mengikuti pembelajaran dengan model pembelajaran Think Pair Share mendapatkan hasil belajar IPA yang lebih tinggi dibandingkan dengan kelompok siswa yang mengikuti pembelajaran dengan model pembelajaran konvensional. Hal ini dilihat dari rata-rata skor hasil belajar IPA siswa. Kelompok eksperimen yang mengikuti pembelajaran dengan menggunakan model pembelajaran Think Pair Share memiliki skor rata-rata skor hasil belajar IPA sebesar 30,26 yang berada pada kategori sangat baik. Sedangkan kelompok kontrol yang mengikuti 
pembelajaran dengan model pembelajaran konvensional memiliki rata-rata skor hasil belajar IPA sebesar 28,40 yang berada pada kategori baik.Berdasarkan pengujian hipotesis dengan menggunakan uji-t, diketahui thit $=2,60$ dan ttab dengan $\mathrm{dk}=37$ dan taraf signifikansi $5 \%$ adalah 2,03. Hasil perhitungan tersebut menunjukkan bahwa nilai thit lebih besar dari nilai ttab (thit $>$ ttab), sehingga hasil penelitian adalah signifikan. Hal ini menunjukkan bahwa terdapat perbedaan hasil belajar IPA antara siswa yang mengikuti pembelajaran dengan model pembelajaran Think Pair Share dengan siswa yang mengikuti pembelajaran dengan model pembelajaran konvensional.Pembelajaran dengan menggunakan model pembelajaran Think Pair Share Model pembelajaran think pair share (TPS) atau berpikir, berpasangan, dan berbagi adalah jenis pembelajaran yang kooperatif yang dirancang untuk mempengaruhi pola interaksi siswa. Model pembelajaran think pair share adalah salah satu model (tipe) pembelajaran yang memberi kesempatan kepada setiap siswa untuk menunjukkan partisipasi kepada orang lain. Model pembelajaran koperatif tipe Think Pair Share (TPS) ini memberi kesempatan sedikitnya delapan kali lebih banyak kepada siswa untuk dikenali dan menunjukkan partisipasi mereka kepada orang lain. Keunggulan teknik ini adalah optimalisasi partisipasi siswa

Model pembelajaran Think Pair Share dapat mengoptimalkan partisipasi siswa dalam mengeluarkan pendapat, dan meningkatkan pengetahuan. Siswa meningkatkan daya pikir (thinking) terlebih dahulu, sebelum masuk ke dalam kelompok berpasangan (pairing), kemudian di bagi ke dalam kelompok (sharing). Pada tipe TPS setiap siswa saling berbagi ide, pemikiran atau informasi yang mereka ketahui tentang permasalahan yang diberikan oleh guru, dan bersama-sama mencari solusinya. Hal ini dapat membuat siswa meninjau dan memecahkan permasalahan yang dari sudut yang berbeda, namun menuju ke arah jawaban yang sama. Hal ini sesuai dengan tujuan model pembelajran Think Pair Share menurut Trianto dalam Wahyuni (2013) yaitu, "Tujuan pembelajaran kooperatif TPS adalah a) dapat meningkatkan kinerja siswa dalam tugas-tugas akademik, b) unggul dalam membantu siswa memahami konsep-konsep yang sulit, c) membantu siswa menumbuhkan kemampuan berpikir kritis.

Terdapat tiga langkah pembelajaran dalam model pembelajaran Think Pair Share yaitu berpikir, berpasangan, dan berbagi.

Pada langkah pertama yaitu berpikir, siswa menggunakan waktu beberapa menit untuk berpikir sendiri mengenai jawaban atau masalah yang diberikan oleh guru. Kelebihan dari tahap ini menurut Atik dalam Wahyuni (2013) adalah adanya teknik "time" atau waktu berfikir yang memberikan kesempatan pada siswa untuk berpikir mengenai jawaban mereka sendiri sebelum pertanyaan tersebut dijawab oleh siswa lain. Selain itu, guru dapat mengurangi masalah adanya siswa yang berbicara, karena tiap siswa memiliki tugas untuk dikerjakan sendiri.

Pada langkah kedua, siswa berpasangan dan mendiskusikan apa yang mereka peroleh. Interaksi selama waktu yang disediakan dapat menyatukan jawaban jika suatu pertanyaan yang diajukan atau menyatukan gagasan apabila suatu masalah khusus yang diidentifikasi. Hal ini didukung oleh pendapat Atik dalam Wahyuni (2013) menyatakan bahwa, interaksi selama proses ini dapat menghasilkan jawaban bersama. Setiap pasangan siswa saling berdiskusi mengenai hasil jawaban mereka sebelumnya sehingga hasil yang didapat menjadi lebih baik karena siswa mendapat tambahan informasi dan pemecahan masalah yang lain.

Pada langkah akhir, guru meminta pasangan-pasangan untuk berbagi dengan keseluruhan kelas yang telah mereka bicarakan. Pada langkah ini akan menjadi lebih efektif apabila guru berkeliling dari psangan satu kepasangan yang lainnya. Langkah share (berbagi) merupakan penyempurnaan dari langkah-langkah sebelumnya, dalam arti bahwa langkah ini menolong semua kelompok untuk menjadi lebih memahami mengenai pemecahan masalah yang diberikan berdasarkan penjelasan kelompok lain.

Berbeda halnya dengan pembelajaran dengan model pembelajaran konvensional. Dalam penelitian ini, guru berperan sebagai pemberi informasi kepada siswa, sedangkan siswa berperan memperoleh informasi dengan tepat melalui kegiatan mendengarkan dan membaca informasi. Penjelasan yang diberikan oleh guru masih berorientasi pada buku dan tidak menggunakan model pembelajaran inovatif. Hal ini menyebabkan siswa cenderung menghafalkan setiap konsep yang diberikan dan kurang dapat memahami serta menghubungkan antara materi-materi yang berhubungan. Pada pembelajaran konvensional, penekannanya sering hanya pada penyelesaian tugas, sehingga hasil belajar tidak bertahan lama (mudah dilupakan). Hal ini akan menyebabkan hasil belajar IPA siswa menjadi kurang optimal. Pernyataan tersebut sesuai dengan kelemahan model pembelajaran konvensional, yaitu membuat siswa merasa bosan karenan dalam pemberian materi pembelajaran guru hanya memberikan ceramah kepada siswa sehingga sisa tidak mengerti dan menjadi penerima yang pasif akibatnya konsep yang diberikan tidak dikuasai. proses pembelajaran dengan 
menggunakan model konvensional kurang memberikan banyak kesempatan siswa untuk berperan akatif dalam pembelajaran, sehingga tidak terjadi interaksi yang multi arah (gurusiswa, siswa-siswa, siswa-guru) dalam proses pembelajaran.

Keberhasilan penerapan model pembelajaran Think Pair Share pada siswa, juga didukung oleh penelitian yang dilakukan oleh Suryaningsih (2016), yang menunjukan bahwa hasil belajar IPA siswa yang mendapatkan perlakuan model pembelajaran Think Pair Share lebih baik dari pada hasil belajar IPA siswa yang tidak mendapatkan perlakuan model pembelajaran berorientasi Think Pair Share. Sejalan dengan penelitian tersebut, Wahyuni melakukan penelitian tahun pelajaran 2013/2014 yang hasilnya dapat menunjukan bahwa model pembelajaran TPS berpengaruh positif terhadap pemahaman konsep IPA siswa.

Jadi agar mencapai hasil belajar yang baik, siswa perlu mengalami sendiri penemuan konsep tersebut melalui diskusi bersama kelompok belajarnya maupun melalui guru, sehingga hasil belajar yang diperoleh siswa akan bertahan lama. Siswa juga diberi kesempatan untuk bertanya dan berpendapat dalam pembelajaran guna mengembangkan kemampuannya dalam berkomunikasi.

\section{Simpulan dan Saran}

Berdasarkan tujuan penelitian dan pembahasan, maka dapat disimpulkan bahwa, terdapat perbedaan yang signifikan dari hasil belajar IPA antara siswa yang dibelajarkan dengan model pembelajaran Think Pair Share (TPS) dan siswa yang belajar dengan model pembelajaran Konvensional di SD Gugus I Kecamatan Tembuku Tahun Pelajaran 2017/2018. Hal ini dibuktikan dengan rata-rata skor hasil belajar IPA kelompok eksperimen yang lebih tinggi dan berkategori sangat baik, dibandingkan kelompok kontrol yang memiliki skor rata-rata hasil belajar IPA yang lebih rendah dengan kategori baik.

Adapun saran yangd dapat diberikan dalam penelitian ini adalah kepala sekolah diharapkan dapat menetapkan kebijakan penggunaan model pembelajaran inovatif untuk meningkatkan kualitas sekolah. Salah satunya yaitu model pembelajaran Think Pair Share (TPS). Selain itu, guru diharapkan guru dapat menerapkan model pembelajaran Think Pair Share (TPS) sebagai solusi untuk mengatasi permasalahan belajar peserta didik. Mengingat keterbatasan penelitian ini, peneliti lain diharapkan dapat lebih mengembangkan penelitian mengenai model pembelajaran Think Pair Share (TPS).

\section{Daftar Pustaka}

Antara, Putu Aditya \& I Gusti Komang Ariprasetya Agus (2010). "Peningkatan Kemampuan Berpikir Kritis Anak Melalui Metode Bermain Peran". Jurusan Pedagogik-FIP-UPI dan Asosiasi Pendidikan Profesi Guru SD, Nomor 2, (hlm.245-256)

Giri, Putu Elsa Yulian Vitriani. 2014. Pengaruh Model Self Regulated Learning (SRL) Terhadap Pengetahuan Metakognitif IPA Pada Siswa Kelas IV Semester II Di Gugus I Kecamatan Busungbiu Tahun Pelajaran 2014/2015.

Megawati, Priarti. 2012. Meretas Permasalahan Pendidikan Di Indonesia . Jurnal Formatif 2(3): 227-234 ISSN: 2088-351X

Munirah. 2015. Sistem Pendidikan Di Indonesia: Antara Keinginan Dan Realita . Jurnal Auladuna, Vol. 2 No. 2 Desember 2015: 233-245

Riastini, Putu Nanci. 2016. Pembelajaran IPA SD. Singaraja: Universitas Pendidikan Ganesha.

Ruhimat, Toto. 2013. Tim Pengembangan MKDP Kurikulum dan Pembelajaran. Jakarta: Rajawali Pers

Santyasa, I Wayan. 2012. Perencanaan dan Desain Sistem Ajar Perguruan Tinggi Pembelajaran Inovatif . Singaraja: Undiksha Press.

Saat, Sulaiman. 2015. Faktor-Faktor Determinan Dalam Pendidikan (Studi Tentang Makna Dan Kedudukannya Dalam Pendidikan) . Jurnal Al-Ta'dib Vol. 8 No. 2, Juli-Desember 2015 
Susanto, Ahmad. 2013. Teori Belajar dan Pembelajaran di Sekolah Dasar. Jakarta: Kencana.

Warsono.2017. Guru: Antara Pendidik, Profesi, Dan Aktor Sosial . Journal of Society \& Media 2017, Vol. 1(1) 1-10

Wahyuni, Ridha Sri. 2013. Hakikat Model Kooperatif Tipe Think Pair Share. Diakses tgl 2 Januari 2018. http://ridha90.blogspot.co.id/2013/05/hakikat-model-kooperatif-tipethink.html

Widodo. 2013. Peningkatan Aktivitas Belajar Dan Hasil Belajar Siswa Dengan Metode Problem Based Learning Pada Siswa Kelas Viia Mts Negeri Donomulyo Kulon Progo Tahun Pelajaran 2012/2013 . Jurnal Fisika Indonesia No: 49, Vol XVII, Edisi April 2013 ISSN : 1410-2994 